\title{
Otel İşgörenlerinin Örgütsel Sinizm Algıları ve İş Performansları Arasındaki İlişki: Kars Illinde Bir Araştırma \\ (The Relationship Between Organizational Cynicism Perception and Work Performance of Hotel Staff; A Research in Kars Province)
}

\author{
Serkan NAKTIYOK (D) a Ethem TOPÇUOĞLU iD b Erman KAYGIN iD c \\ a Kafkas Üniversitesi, İktisadi ve İdari Bilimler Fakültesi, Kars, Türkiye. snaktiyok@kafkas.edu.tr \\ b Kafkas Üniversitesi, Sosyal Bilimler Enstitüsü, Kars, Türkiye. ethemtopcuoglu@kafkas.edu.tr \\ c Kafkas Üniversitesi, Sosyal Bilimler Enstitüsü, Kars, Türkiye. ermankaygin25@hotmail.com
}

\begin{tabular}{|c|c|}
\hline MAKALE BİLGİSi & ÖZET \\
\hline Anahtar Kelimeler: & Amaç - Kars İl Merkezinde bulunan otellerde istihdam edilen işgörenler çalışmanın evrenini \\
\hline $\begin{array}{l}\text { Örgütsel Sinizm } \\
\text { İș Performansı }\end{array}$ & $\begin{array}{l}\text { oluşturmaktadır. Yapılan çalışmanın temel amacı otel işgörenlerinin örgütsel sinizm ve iş performansı } \\
\text { arasındaki ilişkinin belirlenmesidir. }\end{array}$ \\
\hline Bilişsel Sinizm & Yöntem - Anket formu demografik değişkenler, Karacaoğlu ve İnce (2012) tarafından Türkçeye \\
\hline Duygusal Sinizm & uyarlanmış Örgütsel Sinizm Ölçeği ile Avunduk (2016) tarafından hazırlanan İş Performansı Ölçeğinden \\
\hline Davranışsal Sinizm & $\begin{array}{l}\text { oluşmaktadır. Anket basit tesadüfî örneklem şeklinde araştırma evreninde bulunan otel işgörenlerine } \\
\text { uygulanmıştır. } 153 \text { kişilik evrenden } 138 \text { kişiye anket uygulanmış ve } 126 \text { adet anket sonucu }\end{array}$ \\
\hline $\begin{array}{l}\text { Gönderilme Tarihi } 28 \text { Ocak } \\
2020\end{array}$ & $\begin{array}{l}\text { değerlendirmeye alınarak veriler elde edilmiştir. Veriler SPSS ve AMOS programları ile incelenerek } \\
\text { bulgular elde edilmiştir. }\end{array}$ \\
\hline $\begin{array}{l}\text { Revizyon Tarihi } 5 \text { Nisan } \\
2020 \\
\text { Kabul Tarihi } 4 \text { Mayıs } 2020\end{array}$ & $\begin{array}{l}\text { Bulgular-Genç işgörenlerin hırslı olması ve hızlı bir şekilde mevki sahibi olmak istemelerinin bir sonucu } \\
\text { olarak daha sinik oldukları değerlendirilmektedir. Örgütsel sinizm ile eğitim arasında özellikle ön lisans } \\
\text { düzeyinde anlamlı bir farklılığın bulunduğu görülmüştür. }\end{array}$ \\
\hline $\begin{array}{l}\text { Makale Kategorisi: } \\
\text { Araştırma Makalesi }\end{array}$ & $\begin{array}{l}\text { Tartışma - Yapılan literatür incelemesi sonucunda örgütsel sinizm ile iş performansı arasında negatif } \\
\text { yönlü ve anlamlı bir ilişki olacağı tahmin edilmektedir. Ancak yapılan çalışmada iş performansı ile } \\
\text { örgütsel sinizm ve örgütsel sinizm boyutlarından bilişsel boyut, duygusal boyut arasında anlamlı bir } \\
\text { ilişkinin bulunmadığı sadece davranışsal alt boyut ile iş performansı arasında düşük düzeyde negatif } \\
\text { yönlü ve anlamlı bir ilişkinin bulunduğu tespit edilmiştir. Tespit edilen bu durumun uygulama yapıllan } \\
\text { otellerde işgören sayısının az olması nedeniyle daha samimi ilişkilerin ortaya çıkması sonucu oluştugu } \\
\text { değerlendirilmektedir. }\end{array}$ \\
\hline
\end{tabular}

\begin{tabular}{l}
\hline ARTICLE INFO \\
\hline Keywords: \\
Organizational Cynicism \\
Work Performance \\
Cognitive Cynicism \\
Emotional Cynicism \\
Behavioral Cynicism
\end{tabular}

\section{ABSTRACT}

Purpose - Employers employed in hotels located in Kars City Center constitute the universe of the study. The main purpose of the study is to determine the relationship between organizational cynicism and job performance of hotel employees.

Design/methodology/approach - The questionnaire consists of demographic variables, the Organizational Cynicism Scale adapted to Turkish by Karacaoğlu and İnce (2012) and the Business Performance Scale prepared by Avunduk (2016). The questionnaire was applied to hotel employees in the research universe in the form of a simple random sample. From the 153-person universe, 138 people

Received 28 January 2020 Revised 5 April 2020 Accepted 4 May 2020

Article Classification: Research Article were surveyed and 126 questionnaires were evaluated and data were obtained. The data were analyzed with SPSS and AMOS programs and findings were obtained.

Findings - Young employees are considered to be more cynical as a result of being ambitious and wanting to have a position quickly. There was a significant difference between organizational cynicism and education, especially at associate degree level.

Discussion - As a result of the literature review, it is estimated that there will be a negative and significant relationship between organizational cynicism and work performance. In the study, it was found that there was no significant relationship between work performance and organizational cynicism, cognitive dimension and emotional dimension, but only a low negative and significant relationship between behavioral subdimension and work performance. It is considered that this situation occurs as a result of the fact that more sincere relations emerge as a result of the low number of employees in the hotels where the application is made.

\section{Önerilen Atıf/ Suggested Citation}

Naktiyok, S., Topçuoğlu, E., Kaygın, E. (2020). Otel İşgörenlerinin Örgütsel Sinizm Algıları ve İş Performansları Arasındaki İlişki: Kars İlinde Bir Araştırma, İşletme Araştırmaları Dergisi, 12 (2), 1239-1255. 


\section{Giriş}

Kars, Kuzeydoğu Anadolu'da yer alan Türkiye'nin en yüksek rakımına sahip yerleşim alanlarından biridir. Rakım ve iklim şartları nedeniyle tarım imkânları ve alanları kısıtlanmakta olup, Kars ekonomisi genel olarak birkaç temel unsura bağlı kalmaktadır. Ekonomik açıdan çimento ve şeker fabrikası dışında sanayi kuruluşu bulunmamaktadır. Halkın genel geçim kaynağı olarak hayvancllık ve süt ürünleri üretimi ön plana çıkmaktadır. Son zamanlarda Doğu Ekspresi'nin popülerliğinin artması ile beraber turizmde ekonomik açıdan önemli hale gelmiştir. Bölgesel kalkınmanın, istihdam imkânlarının ve ekonomik gelişiminin sağlanması yönüyle turizmin etkisi her geçen gün daha çok hissedilmektedir. Kars'ın turizm birleşenlerini Sarıkamış Şehitlikleri, kar sporları, Ani Ören Yeri, Baltık Mimarisi binalar, hediyelik kaşar ve bal, Çıldır Gölü üzerinde atlı kızak, hengel, piti, kaz eti gibi yöresel tatların sunulduğu alanlar, aşıklar atışması, Kafkas Dansları oluşturmaktadır. Bahsedilen geniş yelpazede turistlerin Kars'ın güzelliklerini keşfetmeleri için bir günlük süre yeterli olmayıp konaklama yapılması zaruri bir unsur olarak karşımıza çımaktadır.

Konaklama tesisleri, kişilerin günün yorgunluğunu atlatabileceği ve ertesi güne daha iyi başlamasını sağlayan, içerisinde yüzme havuzu, spor tesisleri, dinlenme ve yemek salonlarını barındıran komplekslerdir. Tesislerde bulunan imkânlar ile beraber işgörenlerin sunduğu hizmetin niteliği ve müşteride yarattı̆̆ı etkide önemli bir birleşendir. Bu açıdan kaliteli ve iyi hizmet tüketicinin tekrardan Kars'a gelme niyetini etkileyen bir unsur olarak karşımıza çıkmaktadır. Kaliteli ve iyi hizmetin azalması boyutunda örgütsel sinizmin etkili bir faktör olduğu daha önce yapılan çalışmalar ile tespit edilmiştir. Daha önce yapılan akademik çalışmalar sonucunda işgörenlerin örgütsel sinizm düzeyinin artması, işgörenlerin örgütsel bağlllığının, iş doyumunun ve örgütsel adalet algısının azalmasına, işe yabancılaşmanın, örgütsel tükenmişliğin ve işten ayrılma niyetinin artması neden olmaktadır. Örgütsel sinizm aynı zamanda iş performansını da olumsuz etkileyen bir unsur olarak araştırılması gereken bir unsurdur. Buradan hareket ile örgütsel sinizm arttıkça örgütte olumsuz davranış ve tutumların artacağı, bu nedenle işgörenlerin örgüt içerisinde gösterdikleri iş performanslarında azalmanın olacağı düşünülmektedir.

Kars'a gelen turistlerin uzun bir yolculuk sonucunda dinlenmeleri ve ertesi gün gerçekleşecek faaliyetlere daha etkin katılması ekonomik katkıyı daha çok artıracaktır. Konaklama işletmeciliğinde işgörenlerin iş performansının yüksek olması, müşteri memnuniyetinin sağlanmasında önemli bir unsurdur. Örgütsel Sinizm kişilerin işe olan ilgisini azaltan ve kişilerin iş performansını düşüren bir etmendir. Kars İlinde bulunan konaklama işletmelerinin örgütsel sinizm düzeylerinin tespit edilerek iş performansı ile ilişkisini belirlemek çalışmanın ana amacını oluşturmaktadır. Yapılan bu çalışma sonucunda konaklama işletmelerinin sorunlarının tespit edilerek, iş performansının artırılması ve örgütsel sinizmin azaltılması konusunda çözüm önerilerinde bulunulmaktadır.

\section{Literatür Taraması}

Örgütsel sinizm ve iş performansını ayrı ayrı inceleyen birçok çalışma literatürde yer almaktadır. Ancak literatürde iş performansı ve örgütsel sinizmi birlikte inceleyen çalışma sayısı az miktarda bulunmaktadır. Bu az sayıda çalışmaların ağırlıklı olarak akademisyenler üzerinde yoğunlaştığı, konaklama işletmeciliği alanında bir çalışmanın olmadığı tespit edilmiştir.

\section{Örgütsel Sinizm}

Sinizm M.Ö. 5. Yüzyıla kadar uzanan tarihsel bir geçmişe sahiptir. Sinizm, Antik Yunanistan'da bir yaşam ve düşünce sistemi olarak ortaya çıkmıştır. Sokrates'in ölmesi ve Atina'nın işgal edilmesi ile birlikte Antisthenes sade ve basit bir yaşam sürmeye karar vermiştir. Antisthenes'e göre önemli olan erdem ve kendi kendine yeterliliktir. Antisthenes tarafından bu erdem ve kendi kendine yeterliliklere ulaşabilmek için sosyal ve ahlaki değerlerlerden uzaklaşılması, geleneklere aykırı ve özgür bir yaşam tarzı ifade edilmiştir. Antisthenes'den sonra bu fikirleri benimseyen Sinoplu Diyojen (MÖ. 404-323), banyo yapmayarak, iğrenç şeyler yiyerek, ahlaksız davranışlarda bulunarak insanları kızdırmış ve toplum kurallarına aykırı bir yaşam sürdürmüştür. İnsanlar Sinoplu Diyojen'in köpekleştiğini savunarak Yunanca köpeksi anlamına gelen "kinik" kavramını

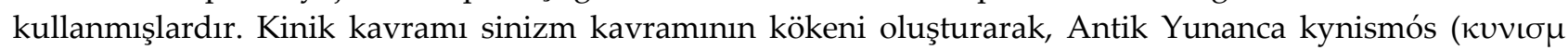
olarak)'dan gelmektedir (Kaşka Üreten ve Gemlik, 2016:443). Günümüzde sinizm çaresizlik, umutsuzluk, hayal kırıklığı, bitkinlik ile karakterize edilen kişilere karşı aşağılama, iğrenme ve güvensizlik ile sonuçlanan psikolojik bir durumdur. Sinizm hakkında ortak düşünce; dürüstlük, doğruluk ve samimiyet gibi ahlaki 


\section{S. Naktiyok - E. Topçuoğlu - E. Kaygin 12/2 (2020) 1239-1255}

erdemlerin bireysel çıarlar için feda edilmesidir (James, 2005:6). Andersson (1996: 1397) tarafından sinizm, bireyler, gruplar, ideolojik düşünceler, sosyal topluluklar veya kurumlara karşı güvensizlik, küu̧ümseme, umutsuzluk ve hayal kırıklığı yaratan genel veya özel bir tutum olarak tanımlanmaktadır. Sinizmin örgütsel sinizm, toplumsal sinizm, işgören sinizmi, örgütsel değişim sinizmi, mesleki sinizm türleri (Ekinci, 2019:163164) bulunmakta olup bu çalışmada örgütsel sinizm üzerinde durulacaktır.

Abraham (2000:270)'a göre örgütsel sinizm bir örgütün dürüstlükten yoksun olduğuna ilişkin işgören üzerinde olumsuz duygusal tepkiye, itibar zedeleyici ve eleştirel bir davranışa yol açan bir kavramdır. Helvacı ve Çetin (2012:1480'e göre örgütsel sinizm, işgörenlerin yöneticilerinin gerçek karakterini yansıtmaması sebebiyle kararlarına inanmadıkları ve niyetlerine güvenmedikleri inancının karşılığı olarak işgörenlerin örgüte karşı olumsuz bir tutum almasını ifade etmektedir. Wilkerson vd. (2008:2274) tarafından örgütsel sinizm, kişilerde hayal kırıklığına neden olan haksız uygulamaların bir sonucu olarak geliştirilen öğrenilmiş bir tutum olarak ifade edilmektedir. Fitzgerald (2002:1)'a göre örgütsel sinizm, işgörenlerin genel tutum ve kişilik özelliklerinden ziyade kurumun politikalarına ve uygulamalarına bir tepki olarak yorumlanmalıdır. Bunun sonucu olarak işgörenler üzerinde işe ilgisizlik, işten istifa, genel ve anlamsız umutsuzluk, başkalarına güvenmeme, hayal kırıklığı, iş yerinde düşük performans ve örgütsel tükenmişlik yaşanmaktadır.

Dean vd. (1998:346) tarafından örgütsel sinizm kavramı, işgörenin örgüte karşı geliştirdiği olumsuz tutumlar olarak tanımlanmaktadır. Bu tutumlar üç boyutta ele alınmaktadır. Bilişsel boyut, işgörenin örgütsel uygulamaların dürüstlükten yoksun olduğu inancını temsil etmektedir (Dean vd., 1998:348). Örgütlerde sinik özellikler gösteren işgörenler genellikle örgütsel eylemlerin gizli nedenleri olduğuna ve yöneticilerin çıkarlarının ön planda yer aldığına inanmaktadırlar. Bu nedenle uygulanan bir eylemin örgüt tarafından açıklanan nedenler sebebiyle gerçekleştirilmek istendiğine inanmak istemezler (Brandes ve Das, 2006: 237). Duygusal boyut, işgörenlerin duygusal durumunu bozan sıkıntı, utanç, nefret, öfke gibi güçlü olumsuz duyguların gelişimini içermektedir (Abraham, 2000: 269). Örgütsel sinizmin duygusal boyutu ile ilgili olarak örgütteki sinik bireyler örgüte karşı saygısız ve öfkeli olabilmekte, ayrıca sinik bireyler örgütlerini düşündüklerinde acı, nefret ve utanç hissetmektedir. Davranışsal boyut, işgörenler bu boyutta genellikle aşağılayıcı davranışları içeren olumsuz davranışlara eğilim göstermektedir. Bireylerin sinik tutumlarının ifadesi olarak ortaya çıkan en belirgin davranış, örgüte yönelik eleştiridir. Çeşitli şekillerde ortaya çıkabilecek bu davranışların en önemlisi, kurumun dürüstlük ve samimiyet gibi değerlerden yoksun olduğunun ifade edilmesidir (Dean vd., 1998: 346).

Örgütsel sinizm konusunda ülkemiz ve yurtdışında birçok çalışma olmasına rağmen özellikle otel işgörenleri ile ilişkili araştırmalar konunun başlığına uygun olarak ön plana çıkarılmıştır. Örgütsel sinizm konusu ile ilgili yapılan bazı akademik çalışmalar şunlardır;

Altınöz vd. (2016) tarafından Ankara'da bulunan 4 ve 5 yıldızlı otellerde işgören 210 kişiye yönelik yapılan araştırmada örgütsel bağlllık ile örgütsel sinizm arasında negatif yönlü anlamlı bir ilişkinin bulunduğu belirlenmiştir.

Bernerth vd. (2007) tarafından 117 kişiye yönelik yapılan araştırmada örgütsel adaletin alt boyutları ile örgütsel sinizm arasında negatif yönlü ve anlamlı bir ilişkinin bulunduğu, örgütsel değişim bağlllığı ile örgütsel sinizm arasında anlamlı bir ilişkinin bulunduğu belirlenmiştir.

Çalışkan vd. (2015) tarafından İstanbul'da bulunan 4 ve 5 yıldızlı çok uluslu otel gruplarında beyaz yakalı olarak işgören 160 kişi üzerinde yapılan araştırma sonucunda kültürel zekâsı yüksek olan liderin örgütte farklı bir örgütsel iklim yaratarak örgütsel sinizmi azalttığı tespit edilmiştir.

Çetinkaya ve Özkara (2015) tarafından Kapadokya Bölgesinde bulunan 4 ve 5 yıldızlı otellerde işgören 720 kişiye yönelik yapılan araştırmada psikolojik sözleşme ihlali algısı ile örgütsel sinizm arasında düşük düzeyde pozitif yönlü bir ilişkinin bulunduğu belirlenmiştir.

Demir vd. (2018) tarafından İstanbul'da bulunan beş yıldızlı otellerde 148 kişi üzerinde yapılan araştırma sonucunda örgütsel sinizm ile işe yabancılaşma davranışı arasında pozitif yönlü ve anlamlı bir ilişki bulunduğu tespit edilmiştir. Ayrıca örgütsel sinizmin, işe yabancılaşma davranışının yüzde 57'sini açıkladığı belirlenmiştir. 
Gün (2016) tarafından Bitlis İlinde bulunan 3 ve 4 yıldızlı otellerde işgören 99 kişi üzerinde yapılan araştırma sonucunda bürokratik örgüt yapılanmasının örgütsel sinizm ile pozitif yönlü ve anlamlı ilişkisinin bulunduğu belirlenmiştir. Yenilikçi ve destekleyici örgüt yapılarının ise örgütsel sinizm ile negatif yönlü ve anlamlı ilişkisinin bulunduğu tespit edilmiştir.

Gün (2017) tarafından Bitlis İlinde bulunan 3 ve 4 yıldızlı otellerde işgören 99 kişi üzerinde yapılan başka bir araştırmada işgörenlerin demografik değişkenlere göre örgütsel sinizm düzeyleri belirlenmiştir. Yapılan çalışma sonucunda işgörenlerin sinizm düzeyleri ile cinsiyet, yaş ve çalışılan birime göre anlamlı farklılık, medeni hal, öğrenim durumu, gelir düzeyi ve çalışma süresine göre ise farklılık bulunmadığı belirlenmiştir.

Güzel ve Ayazlar (2014) tarafından Didim'de bulunan 4 ve 5 yıldızlı otellerde işgören 218 kişi üzerinde yapılan araştırma sonucunda örgütsel adaletin, örgütsel sinizm ile arasında negatif yönlü, anlamlı ilişki bulunduğu, işten ayrılma niyeti ile arasında sadece işlemsel adalet boyutunda negatif yönlü bir etkinin söz konusu olduğu belirlenmiştir.

İbrahimağaoğlu ve Can (2017) tarafından İstanbul'da yer alan bir otelde 155 otel işgöreni üzerinde yapılan araştırma sonucunda örgütsel sinizm ile tükenmişlik arasında anlamlı ve pozitif yönlü bir ilişkinin bulunduğu belirlenmiştir.

Kaygın ve Kavak (2017) tarafından bir kamu üniversitesinde görevli 160 akademik personel üzerinde yapılan araştırma sonucunda akademisyenlerin genel sinizm ve örgütsel sinizm düzeylerinin orta seviyede olduğu belirlenmiştir.

Korkmaz Orhan ve Ünüvar (2019) tarafından Konya İlinde bulunan 3, 4 ve 5 yıldızlı otellerde işgören 322 kişi üzerinde yapılan araştırmada örgütsel adalet algısı ile örgütsel sinizm arasında negatif yönlü anlamlı bir ilişki tespit edilmiştir.

Kosa (2019) tarafından Konya, Aksaray ve Karaman İllerinde bulunan 278 banka işgörenini kapsayacak şekilde yapılan araştırmada örgütsel sinizm ile iş doyumu arasında negatif yönlü ve anlamlı bir ilişkinin olduğu belirlenmiştir. Yapılan çalışmada banka işgörenlerinin örgütsel sinizm algılarının düşük düzeyde, iş doyumu düzeylerinin ise orta düzeyde olduğu tespit edilmiştir.

Liceli ve Hassan (2019) tarafından İstanbul'da bulunan 4 ve 5 yıldızlı otellerde işgören 273 kişiye yönelik yapılan araştırmada otel yöneticilerinin uyguladığı, ödüllendirme gücü, uzmanlık gücü ve karizmatik gücün örgütsel sinizm üzerinde negatif yönlü etkisinin bulunduğu, yasal güç kullanımının ise pozitif yönlü etkisinin bulunduğu tespit edilmiştir.

Yapılan inceleme sonucunda işgörenlerin örgütsel sinizm düzeyinin artmasının, örgütsel bağlllı̆̆ın azalmasına (Altınöz vd, 2016:312), iş doyumunun azalmasına (Kosa, 2019:207), örgütsel adaletin azalmasına (Güzel ve Ayazlar, 2014:138; Korkmaz Orhan ve Ünüvar, 2019:459), işe yabancllaşmanın artmasına (Demir vd., 2018: 248), örgütsel tükenmişliğin artmasına (İbrahimağaoğlu ve Can, 2017:198), örgütsel iklimi olumsuz yönde etkilenmesine (Çalışkan vd., 2015:8), işten ayrılma niyetinin artmasına (Güzel ve Ayazlar, 2014:138), psikolojik sözleşme ihlali algısının artmasına (Çetinkaya ve Özkara, 2015:88) neden olduğu belirlenmiştir. Buradan hareket ile örgütsel sinizm arttıkça örgütte olumsuz davranış ve tutumların artacağı, bu nedenle işgörenlerin örgüt içerisinde gösterdikleri iş performanslarında azalmanın olacağı düşünülmektedir.

\section{İş Performansı}

Performans, bireyler ve işletmeler tarafından belirlenen hedeflere ulaşmak üzere harcanan çaba ve emek sonucunda ulaşılan başarı düzeyidir (Büte, 2011: 177). Diğer bir ifade ile performans, işgörenlerin işlerinde ne yapmaları gerektiği ile şahsen yaptıklarının arasındaki ilişki olarak tanımlanmaktadır (Bayram, 2006:47-48). Erdoğan (1991: 154)'a göre performans, kişilerin veya örgütlerin bir işi tanımlanmış özellikleri ve yetenekleri doğrultusunda, kabul edilebilir çizgiler dâhilinde gerçekleştirmesidir. Başaran (1991:179)'a göre örgütsel davranış açısından performans, örgütsel amaçlara ulaşmak için işgörenin görevi ile ilgili eylem ve prosedürlerin bir sonucu olarak tanımlamaktadır. Chui (2004:82)'ye göre iş performansı, bir işin yerine getirilmesi için çaba harcanmasını, harcanan çaba sonucunda tamamlanmasının sayısal olarak ifadesidir. İş performansı işin tanımlanmasını, harekete geçmeyi, işin yerine getirilmesini kapsayan bir süreçtir. İş performansı konusunda ülkemiz ve yurtdışında birçok çalışma olmasına rağmen özellikle otel işgörenleri ile 
ilişkili araştırmalar konunun başlı̆̆ına uygun olarak ön plana çıkarılmıştır. İş performansı konusu ile ilgili yapılan bazı akademik çalışmalar şunlardır;

Çakır ve Gözoğlu (2019) tarafından Şanlıurfa' da 50 ve üzerinde personeli bulunan 4 yıldızlı otellerde işgören 194 kişiye yönelik yapılan araştırmada algılanan kurumsal itibar ile iş performansı arasında pozitif yönlü ve anlamlı bir ilişkinin bulunduğu, algılanan kurumsal itibarın işten ayrılma niyeti ile negatif yönlü anlamlı bir ilişkisinin bulunduğu belirlenmiştir.

Çetinsöz ve Akdağ (2015) tarafından Antalya' da bulunan 5 yıldızlı otellerde işgören 402 kişiye yönelik yapılan araştırmada iş performansı ile on maddelik kişilik özellikleri ölçeği uygulanmıştır. İş performansı ile kişilik özelliklerinin alt boyutu olan duygusal ve yumuşak başlı olma, dışa dönük ve sorumlu olma alt boyutlarında düşük düzeyde pozitif yönlü anlamlı bir ilişkinin bulunduğu, deneyime açıklık boyutunda anlamlı bir farklılı̆̆ın bulunmadığı tespit edilmiştir.

Demir (2015) tarafından Muğla' da bulunan 5 yıldızlı otellerde işgören 399 kişiye yönelik yapılan araştırmada örgütsel birey uyumu ölçeği , işte kalma niyeti ölçeği ve iş performansı ölçeği kullanılmıştır. Kullanılan ölçekler arasında pozitif yönlü anlamlı ilişki ve etkinin bulunduğu tespit edilmiştir.

Demir ve Öztürk (2019) tarafından Marmaris'te bulunan 5 yıldızlı otellerde yiyecek ve içecek bölümünde işgören 313 kişiye yönelik yapılan araştırmada işyeri atmosferinin alt boyutları renk, müzik, düzen, iş ortamı ve zemin ile iş performansı arasında pozitif yönlü anlamlı ilişkinin bulunduğu tespit edilmiştir.

Doğan (2018) tarafından Afyonkarahisar'da bulunan 5 yıldızlı termal otellerde işgören 254 kişiye yönelik yapılan araştırmada örgütsel adalet algısı ile iş performansı arasında düşük düzeyde pozitif yönlü anlamlı ilişkinin bulunduğu tespit edilmiştir.

Motowidlo ve Scotter (1994) tarafından ABD Hava Kuvvetlerinde 421 bakım personeli ile yapılan araştırma sonucunda tecrübenin ve eğitimin, iş performansı ile arasında pozitif yönlü ve anlamlı bir ilişkinin bulunduğu tespit edilmiştir.

Özgül Katlav ve Şahin Perçin (2019) tarafından Nevşehir'de bulunan 4 ve 5 yıldızlı otellerde işgören 358 kişiye yönelik yapılan araştırmada etkileme taktikleri algıları ile iş performansı arasında pozitif yönlü ve anlamlı bir ilişkinin bulunduğu, ayrıca bu ilişkide iş kontrol odağının aracılık rolünün bulunduğu belirlenmiştir.

Polat (2019) tarafından Ankara İlinde bulunan okullarda işgören 516 kişiye yönelik yapılan araştırmada öğretim doyumu ile iş performansı arasında düşük düzeyde pozitif yönlü anlamlı ilişkinin bulunduğu tespit edilmiştir.

Şahin ve Çankır (2019) tarafından İstanbul'da kuaför, kişisel bakım hizmetleri, halı yıkama, araç yıkama, dış cephe yenileme gibi işlerde işgören 202 kişiye yönelik yapılan araştırmada sürdürülebilir kalite algısının iş performansı üzerinde pozitif yönlü ve anlamlı bir etkisinin bulunduğu ayrıca bu etki sırasında çalışmaya tutkunluğun aracı rolünün bulunduğu belirlenmiştir.

Yapılan inceleme sonucunda, örgütsel adaletin (Doğan, 2018:41), öğretim doyumunu (Polat, 2019:646), birey örgüt uyumunun ve işte kalma niyetinin (Demir, 2015:66), iş yeri atmosferinin (Demir ve Öztürk, 2019:378379), sürdürülebilir kalite algısının (Şahin ve Çankır 2019:205), etkileme taktikleri algılarının (Özgül Katlav ve Şahin Perçin, 2019: 237 ), algılanan kurumsal itibarın (Çakır ve Gözoğlu, 2019:63), on maddelik kişilik özellikleri ölçeğinin alt boyutu olan duygusal ve yumuşak başlı olma, dışa dönük ve sorumlu olma alt boyutlarında (Çetinsöz ve Akdağ, 2015:7) yaşanan artışların, işgörenlerin iş performansını artırdığı belirlenmiştir. Buradan hareket ile olumlu örgütsel davranışların işgörenlerin iş performanslarını artıracağı düşünülmektedir.

\section{Örgütsel Sinizm ile İş Performansı Arasında İlişki}

Örgütsel sinizm ile iş performansı arasında ilişkinin belirlenmesi maksadıyla yapılan literatür incelemesi sonucunda otel işgörenlerinin dahil olduğu bir çalışmanın literatürde bulunmadığı, daha önce yapılan çalışmaların ise yoğun olarak akademisyenler üzerine uygulandığı belirlenmiştir. Bu kapsamda yapılan bazı çalışmalar şunlardır; 


\section{S. Naktiyok - E. Topçuoğlu - E. Kaygin 12/2 (2020) 1239-1255}

Akdemir vd. (2016) tarafından Munzur ve Kafkas Üniversitelerinde görev yapan 529 akademisyen ve idari personel üzerinde yapılan araştırma sonucunda örgütsel sinizm ile iş performansı arasında negatif yönlü ve anlamlı bir ilişkinin olduğu belirlenmiştir.

Genç (2018) tarafından Bartın İlinde kamu işgörenlerine yönelik olarak yapılan araştırmada algılanan örgütsel adalet ile iş performansı arasında pozitif yönlü, anlamlı bir etkinin bulunduğu, örgütsel sinizm ile algılanan örgütsel adalet arasında negatif yönlü ve anlamlı bir etkinin bulunduğu, örgütsel sinizm ile iş performansı arasında negatif yönlü ve anlamlı bir etkinin bulunduğu tespit edilmiştir.

Kâhya (2013) tarafından Bayburt ve Karadeniz Teknik Üniversitelerinde görevli 105 akademisyen üzerinde yapılan araştırma sonucunda örgütsel sinizmin iş tatmini ile iş performansını negatif yönlü ve anlamlı bir şekilde etkilediği belirlenmiştir.

Topcu vd. (2017) tarafından Ankara' da imalat sanayinde işgören 138 kişi ile örgütsel sinizm, zorunlu örgütsel vatandaşlık davranışları ve iş tatmininin bireysel iş performansına etkileri üzerine araştırma yapılmıştır. Yapılan araştırma sonucunda zorunlu örgütsel vatandaşlık davranışının ve örgütsel sinizmin işgörenlerin performansları üzerinde negatif, iş tatminlerine ise pozitif etkilerinin olduğu tespit edilmiş̧tir.

Uzun (2018) tarafından Giresun'da görev yapan 235 öğretmen üzerinde yapılan araştırma sonucunda öğretmenlerin örgütsel sinizm tutumları ve iş performansları ile örgütsel vatandaşlık davranışları arasında negatif, örgütsel vatandaşlık davranışları ile iş performansları arasında pozitif yönde anlamlı bir ilişki vardır. Öğretmenlerin örgütsel sinizm tutumları iş performansını ve örgütsel vatandaşlık davranışlarını olumsuz etkilemektedir.

Yılmaz ve Polatcı (2018) tarafından 167 akademik personel üzerinde yapılan araştırmada örgütsel sinizm ile iş performansı arasında düşük düzeyde anlamlı ve negatif yönlü bir ilişkinin bulunduğu tespit edilmiştir.

Buradan hareketle yapılan çalışma sonucunda örgütsel sinizm ile iş performansı arasında düşük düzeyde anlamlı ve negatif yönlü bir ilişkinin bulunması beklenmektedir.

\section{Yöntem}

Ülkemizde örgütsel sinizm konusunda yapılan çalışmalarda (Akdemir vd., 2016; Balay vd., 2013; Çalışkan vd., 2015; Demir vd., 2018; Efeoğlu ve İpek, 2011; Gün, 2016; Kosa, 2019; Yılmaz ve Polatc1, 2016) Brandes vd. (1999) tarafından hazırlanan Örgütsel Sinizm Ölçeğinin yaygınlığı sebebiyle araştırmada bu ölçek kullanılmıştır. Söz konusu ölçek Karacaoğlu ve İnce (2012) tarafından Türkçeye çevrilmiş ve güvenirliği test edilerek bilim dünyasına kazandırılmıştır. Söz konusu ölçek bilişsel, duygusal ve davranışsal alt boyutlardan oluşmaktadır. Ölçek bilişsel ( 5 madde), duygusal (4 madde) ve davranışsal (4 madde) olmak üzere toplam 13 sorudan oluşmaktadır. Sorular 1 ile 5 arasında puanlanmaktadır. İş Performansı Ölçeği, Avunduk (2016) tarafından tasarlanan tek boyutta ve on sorudan oluşan bir ölçektir. Avunduk (2016) tarafından oluşturulan ölçeğin 1-4 arasındaki soruları Kirkman ve Rosen (1999) tarafından geliştirilen Sigler ve Pearson (2000) tarafından güncellenen ve Çöl (2008) tarafından Türkçeye uyarlanan sorulardan, 5-8 arasındaki soruları Mowday vd. (1979) tarafından geliştirilen ve Karadal ve Araslı (2009) tarafından Türkçeye uyarlanan sorulardan, 8-10 arasındaki soruları ise Choo (1986) tarafından geliştirilen ve Avunduk (2016) tarafından Türkçeye çevrilen sorulardan oluşmaktadır.

Araştırma Kültür ve Turizm Bakanlığının verileri doğrultusunda Kars İli Merkez İlçesinde bulunan toplam 7 adet (4 yıldızlı 2 adet, 3 yıldızlı 3 adet, 100 odalı belediye belgeli 2 adet) otelde işgörenler üzerinde yapılmıştır (www.kültür.gov.tr). Söz konusu otellere tek tek gidilerek, toplam 153 kişinin çalışmakta olduğu belirlenmiştir. Örgütsel Sinizm Ölçeği ve İş Performansı Ölçeğinden oluşan anket basit tesadüfi örneklem şeklinde araştırma evreninde bulunan otel işgörenlerine uygulanmıştır. Uygulama 01 Aralık 2019 tarihi ile 15 Aralık 2019 tarihleri arasında yapılmışır. Anket 138 otel işgörenine uygulanmış, 12 adet ankette eksik bilgi bulunması sebebiyle çalışmaya dâhil edilmeyerek 126 adet anketten araştırma verileri elde edilmiştir. 153 kişiden oluşan bu evrenin \% 5 tolere edilebilir hata payı ile en az 110 kişiden oluşan bir örneklem grubu ile temsil edilebileceği ileri sürülmüştür (Büyüköztürk vd., 2012: 98).

Araştırmadan elde edilen verilerin normal dağılıp dağılmadığını ölçmek için Kolmogorov-Smirnov ve Shapiro-Wilk testleri uygulanmıştır. Söz konusu testlere ilişkin basıklık ve çarpıklık değerleri $+1,5$ ile $-1,5$ arasında yer alması nedeniyle Denis (2019:28)'e göre örneklem normal dağılmıştır. 
Araştırmada elde edilen verilere KMO (Kaise-Meyer-Olkin Örnekleme Ölçüsü) örneklem yeterlilik ölçütü, araştırma analizinden anlamlı faktörler çıkabileceğini gösteren küresellik derecesi (Barlett'in Küresellik Testi) ve güvenirlik için cronbach alpha testleri uygulanarak sonuçları Tablo 1'de sunulmuştur. Araştırmada açımlayıcı faktör analizi yapılarak faktör yükleri $0,4^{\prime} ı$ altında yer alan Örgütsel Sinizm Ölçeğinin bilişsel boyutundan 1 soru, İş Performansı Ölçeğinden 2 soru çıkarılmıştır. Örgütsel Sinizm Ölçeğinin 3 boyut altında toplandığ1, duygusal boyutun öz değerinin 3,748, açıklanan varyansının \%31,234 olduğu, bilişsel boyutun öz değerinin 3,201, açıklanan varyansını \%26,673 olduğu, davranışsal boyutun öz değerinin 2,968, açıklanan varyansının \%24,734 olduğu ve toplam açıklanan varyansın \%82,641 olduğu belirlenmiştir. İş Performansı Ölçeği bir boyutta toplanarak öz değerinin 5,405, toplam açıklanan varyansın \%67,558 olduğu belirlenmiştir.

Tablo 1. Örgütsel Sinizm ile İş Performansına İlişkin Açımlayıcı Faktör Analizi

\begin{tabular}{|c|c|c|c|c|c|c|c|}
\hline Değişkenler & Boyutlar & İfadeler & Faktör Yükleri & \multicolumn{2}{|c|}{ Cronbach's Alpha } & KMO & $\begin{array}{c}\text { Barlett } \\
\text { Küresellik }\end{array}$ \\
\hline \multirow{12}{*}{ 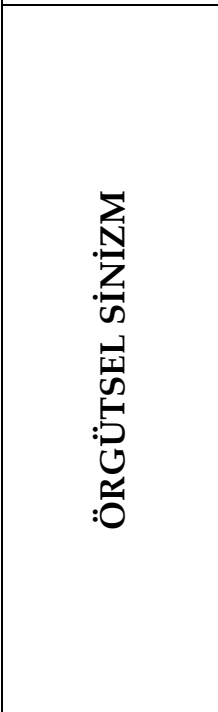 } & \multirow{4}{*}{ 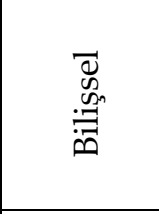 } & bilişsel2 & ,903 & \multirow{4}{*}{0,926} & \multirow{12}{*}{0,946} & \multirow{12}{*}{0,869} & \multirow{12}{*}{$\begin{array}{l}1.549,74 \\
\mathrm{p}<0,001\end{array}$} \\
\hline & & bilişsel3 & 834 & & & & \\
\hline & & bilişsel5 & ,768 & & & & \\
\hline & & bilişsel4 & 662 & & & & \\
\hline & \multirow{4}{*}{ 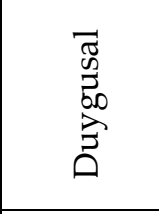 } & duygusal4 & 845 & \multirow{4}{*}{0,949} & & & \\
\hline & & duygusal3 & 821 & & & & \\
\hline & & duygusal2 & 820 & & & & \\
\hline & & duygusal1 & ,772 & & & & \\
\hline & \multirow{4}{*}{ 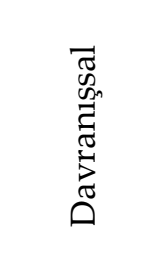 } & davranışsal3 & 864 & \multirow{4}{*}{0,885} & & & \\
\hline & & davranışsal4 & ,833 & & & & \\
\hline & & davranışsal1 & ,726 & & & & \\
\hline & & davranışsal2 & 670 & & & & \\
\hline \multirow{8}{*}{ 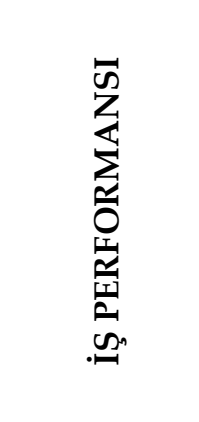 } & \multirow{8}{*}{ 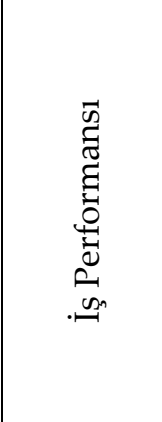 } & performans6 & ,896 & \multirow{8}{*}{\multicolumn{2}{|c|}{0,931}} & \multirow{8}{*}{0,904} & \multirow{8}{*}{$\begin{array}{c}730,88 \\
p<0,001\end{array}$} \\
\hline & & performans8 & ,858 & & & & \\
\hline & & performans3 & 839 & & & & \\
\hline & & performans4 & 838 & & & & \\
\hline & & performans2 & 833 & & & & \\
\hline & & performans7 & 807 & & & & \\
\hline & & performans5 & ,780 & & & & \\
\hline & & performans9 & ,712 & & & & \\
\hline
\end{tabular}

Alpar (2013:849)'a göre tespit edilen değerler yüksek güvenirliktedir. Benzer değerlerin konaklama işletmelerinde etik iklimi ve örgütsel sinizm üzerine çalışma yapan Sarı ve Doğantekin (2016:233) tarafından da örgütsel sinizm için sırasıyla 0,927, 0,894, 0,916 ve 0,808 olarak belirlendiği tespit edilmiştir. Bu kapsamda tespit edilen değerlerin literatür ile uyumlu olduğu belirlenmiştir.

Açımlayıcı faktör analizi sonucunda ortaya çıkan yapının uyumunun ortaya konulması maksadıyla ölçeklere doğrulayıcı faktör analizi uygulanmıştır. Doğrulayıcı Faktör Analizi yorumlaması Yaşlığlu (2017) tarafından belirtilen CMIN/DF için $0<\chi 2 / s d \leq 3$ İyi Uyum; $3<\chi 2 / s d \leq 5$ Kabul Edilebilir Uyum, TLI için 0,95< TLI $\leq 1$ İyi Uyum; 0,90<TLI $\leq$,94 Kabul Edilebilir Uyum, GFI için 0,95< GFI 1 İyi Uyum; 0,90 < GFI 0 ,94 Kabul Edilebilir Uyum, RMSEA için $0 \leq$ RMSEA $\leq$ 0,05 İyi Uyum, 0,05 $\leq$ RMSEA $\leq$ 0,08 Kabul Edilebilir Uyum kıstaslarına göre yapılmıştır. 


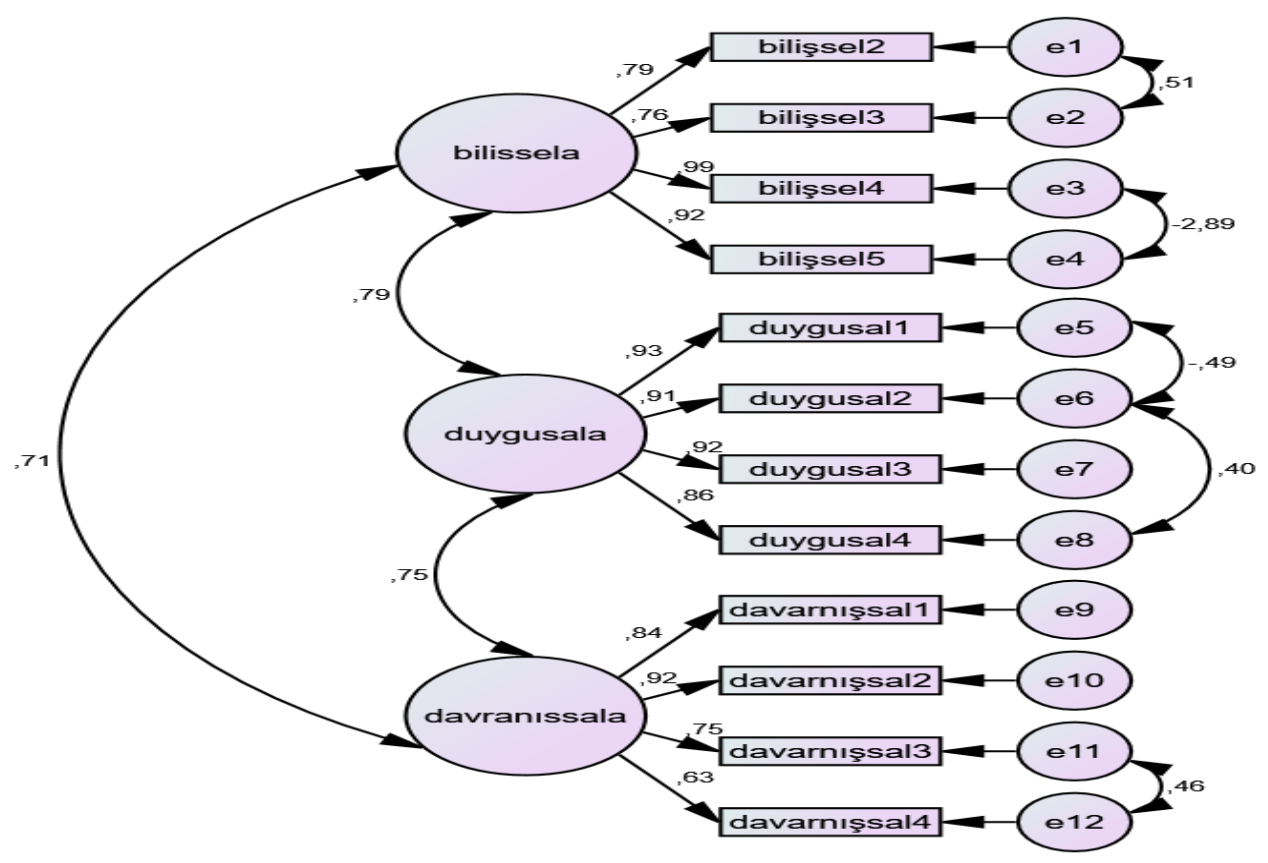

Şekil 1. Örgütsel Sinizm Ölçeğine İlişkin Doğrulayıcı Faktör Analizi

Tablo 2. Örgütsel Sinizm Ölçeğine İlişkin Uyum İndeksi Analizi

\begin{tabular}{ccc} 
İndeksler & Ölçüm & Sonuç \\
\hline CMIN/DF & 2,132 & Iyi Uyum \\
\hline GFI & 0,904 & Kabul Edilebilir Uyum \\
\hline TLI & 0,923 & Kabul Edilebilir Uyum \\
\hline RMSEA & 0,078 & Kabul Edilebilir Uyum \\
\hline
\end{tabular}

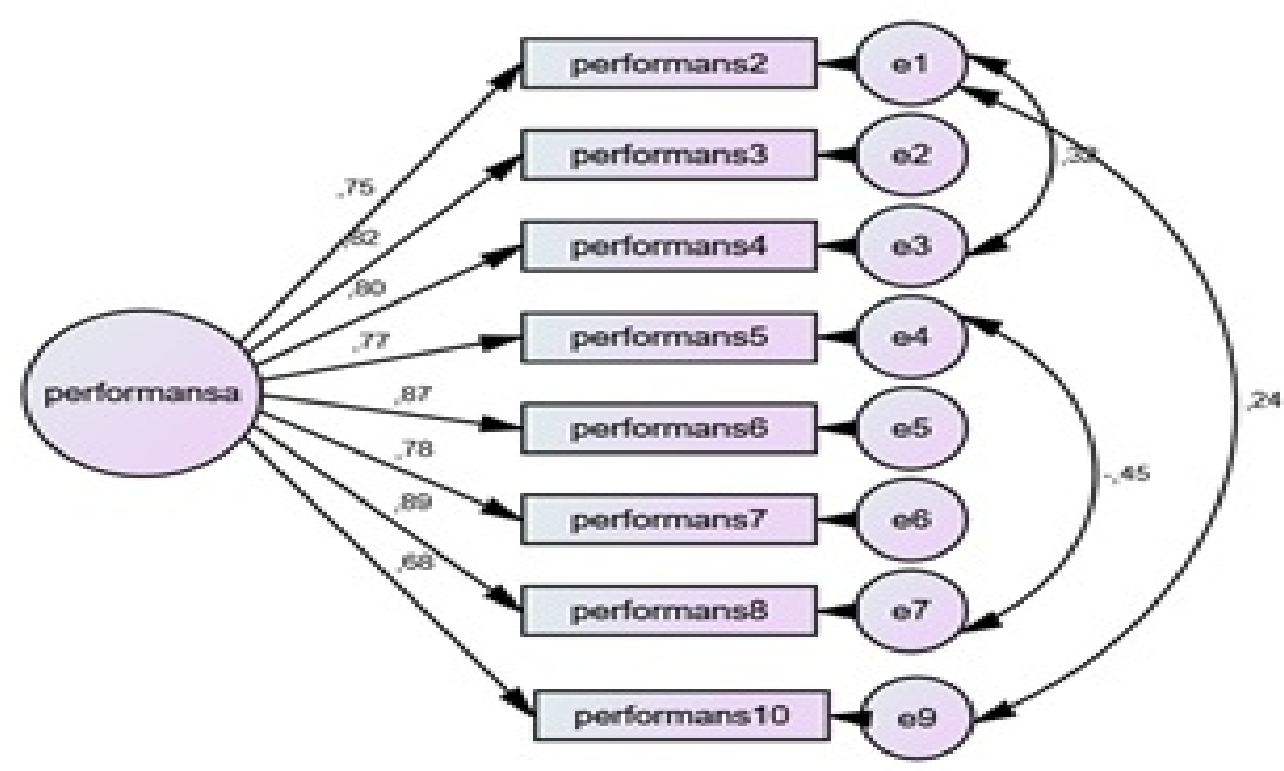

Şekil 2. İş Performansı Ölçeğine İlişkin Doğrulayıcı Faktör Analizi 
S. Naktiyok - E. Topçuoğlu - E. Kaygın 12/2 (2020) 1239-1255

Tablo 3. İş Performansı Ölçeğine İlişkin Uyum İndeksi Analizi

\begin{tabular}{ccc}
\hline Indeksler & Ölçüm & Sonuç \\
\hline CMIN/DF & 1,627 & İyi Uyum \\
\hline GFI & 0,953 & İyi Uyum \\
\hline TLI & 0,976 & İy Uyum \\
\hline RMSEA & 0,071 & Kabul Edilebilir Uyum \\
\hline
\end{tabular}

\section{Bulgular ve Tartışma}

Örgütsel sinizm ve boyutları ile iş performansı arasında nasıl bir ilişki olduğunu belirlemek için öncelikle korelasyon analizinden yararlanılmıştır. Korelasyon analizi iki değişken arasındaki ilişkinin düzeyini veya derecesini ölçen bir yöntemdir. Değişkenler arasında ilişki yoksa " $r$ " harfi ile gösterilen korelasyon kat sayısı 0, aynı yönlü tam ilişki varsa +1, aksi yönlü tam bir ilişki varsa -1 olur (Köksal, 1994).

Tablo 4'de örgütsel sinizm ve boyutları ile iş performansı arasındaki ilişkileri gösteren korelasyon katsayıları verilmektedir. Örgütsel sinizmin alt boyutlarından olan davranışsal sinizm ile iş performansı arasında negatif yönlü ve anlamlı bir ilişki tespit edilmiştir. Örgütsel sinizmin iş performansı ile ilişkisinin bulunmaması ve sadece tek boyutu ile düşük düzeyde anlamlı bir ilişkinin varlığı, uygulama yapılan otellerde işgören sayısının az olması sonucu daha samimi ilişkilerin ortaya çıkması ve sinizmin düşük düzeyde kalarak işgörenlerin performansları üzerine etki etmemesi olarak değerlendirilebilir.

Tablo 4. Örgütsel Sinizm ile İş Performansı Düzeyleri Arasındaki Korelasyon Analizi

\begin{tabular}{|l|c|c|c|c|c|}
\hline BOYUTLAR & $\mathbf{1}$ & $\mathbf{2}$ & $\mathbf{3}$ & $\mathbf{4}$ & $\mathbf{5}$ \\
\hline 1. ÖRGÜTSEL SİNIZM & 1 & & & & \\
\hline 2. BíLIŞSEL BOYUT &, $882^{* *}$ & 1 & & & \\
\hline 3. DUYGUSAL BOYUT &, $909^{* *}$ &, $745^{* *}$ & 1 & & \\
\hline 4. DAVRANIŞSAL BOYUT &, $852^{* *}$ &, $592^{* *}$ &, $657^{* *}$ & 1 & \\
\hline 5. İŞ PERFORMANSI &,- 143 &, 043 &,- 163 &,$- 256^{* *}$ & 1 \\
\hline
\end{tabular}

${ }^{* *} \mathrm{p}<0,01,{ }^{*} \mathrm{p}<0,05$

İşgörenlerin cinsiyeti, medeni durumu, yaşı, gelir düzeyi, eğitim düzeyi ve çalışma süresi kontrol değişkeni olarak alınmış ve bu değişkenler açısından örgütsel sinizm algıları ve iş performansları $t$ testi ve tek yönlü varyans analizi ile (ANOVA) incelenmiştir.

Tablo 5. Otel İşgörenlerinin Cinsiyete Göre Örgütsel Sinizm ve İş Performansı Düzeyleri

\begin{tabular}{|c|c|c|c|c|c|c|}
\hline BOYUTLAR & CINSIYYET & $\mathbf{N}$ & $\overline{\mathbf{x}}$ & Ss & $\mathbf{t}$ & $\mathbf{p}$ \\
\hline \multirow{2}{*}{ ÖRGÜTSEL SİNIZM } & ERKEK & 51 & 2,1471 & ,94098 & \multirow{2}{*}{,- 839} & \multirow{2}{*}{, 087} \\
\hline & KADIN & 75 & 2,3011 & 1,05684 & & \\
\hline \multirow{2}{*}{ BİLİŞSEL BOYUT } & ERKEK & 51 & 2,3088 & 1,10633 & \multirow{2}{*}{,285 } & \multirow{2}{*}{,218 } \\
\hline & KADIN & 75 & 2,2500 & 1,15884 & & \\
\hline \multirow{2}{*}{ DUYGUSAL BOYUT } & ERKEK & 51 & 1,8431 & 1,15754 & \multirow{2}{*}{$-1,279$} & \multirow{2}{*}{,430 } \\
\hline & KADIN & 75 & 2,1100 & 1,14361 & & \\
\hline \multirow{2}{*}{ DAVRANIŞSAL BOYUT } & ERKEK & 51 & 2,2892 & 1,01041 & \multirow{2}{*}{$-1,215$} & \multirow{2}{*}{,056 } \\
\hline & KADIN & 75 & 2,5433 & 1,23940 & & \\
\hline \multirow{2}{*}{ İŞ PERFORMANSI } & ERKEK & 51 & 4,0280 & ,96765 & \multirow{2}{*}{,891 } & \multirow{2}{*}{,358 } \\
\hline & KADIN & 75 & 3,8819 & ,85726 & & \\
\hline
\end{tabular}


S. Naktiyok - E. Topçuoğlu - E. Kaygin 12/2 (2020) 1239-1255

Araştırmaya katılan 51 (\%40,5) kişi erkek, 75 (\% 59,5) kişi ise kadındır. Hair vd. (2014:667) göre t testi aracılığıyla yapılan ölçümün sonucunun $\mathrm{p}$ değerinin 0.05 'den küçük bir değere sahip olması anlamlı bir farklılığın olduğunu göstermektedir. Yapılan $t$ testi sonucunda iş görenlerin cinsiyet durumuna göre ifadeler arasında anlamlı bir farklılık tespit edilmemiştir.

Tablo 6. Otel İşgörenlerinin Medeni Durumuna Göre Örgütsel Sinizm ve İş Performansı Düzeyleri

\begin{tabular}{|c|c|c|c|c|c|c|}
\hline BOYUTLAR & $\begin{array}{l}\text { MEDENI } \\
\text { DURUM }\end{array}$ & $\mathbf{N}$ & $\overline{\mathbf{x}}$ & Ss & $\mathbf{t}$ & $\mathbf{p}$ \\
\hline \multirow{2}{*}{ ÖRGÜTSEL BOYUT } & EVLİ & 38 & 1,9101 & ,90573 & \multirow{2}{*}{$-2,446$} & \multirow{2}{*}{, 031} \\
\hline & BEKAR & 88 & 2,3807 & 1,02505 & & \\
\hline \multirow{2}{*}{ BİLIŞSEL BOYUT } & EVLİ & 38 & 2,0526 & 97287 & \multirow{2}{*}{$-1,445$} & \multirow{2}{*}{,008 } \\
\hline & BEKAR & 88 & 2,3693 & 1,18902 & & \\
\hline \multirow{2}{*}{ DUYGUSAL BOYUT } & EVLİ & 38 & 1,7434 & 1,15444 & \multirow{2}{*}{$-1,667$} & \multirow{2}{*}{396} \\
\hline & BEKAR & 88 & 2,1136 & 1,13961 & & \\
\hline \multirow{2}{*}{ DAVRANIŞSAL BOYUT } & EVLİ & 38 & 1,9342 & 97205 & \multirow{2}{*}{$-3,365$} & \multirow{2}{*}{, 046} \\
\hline & BEKAR & 88 & 2,6591 & 1,16349 & & \\
\hline \multirow{2}{*}{ İŞ PERFORMANSI } & EVLİ & 38 & 4,2744 &, 84246 & \multirow{2}{*}{2,798} & \multirow{2}{*}{161} \\
\hline & BEKAR & 88 & 3,7971 & 89404 & & \\
\hline
\end{tabular}

Araştırmaya katılan 38 (\%30,2) kişi evli, 88 (\%69,8) kişi ise bekârdır. Ölçülen p değerinin örgütsel sinizm, bilişsel ve davranışsal alt boyutunda $0.05^{\prime}$ den küçük olması nedeniyle medeni duruma göre anlamlı bir farklllık gösterdiği tespit edilmiştir. Gün (2017:11) tarafından bekâr otel işgörenlerinin evli otel işgörenlerine göre daha sinik olduğu belirlenmiştir. Bekâr işgörenlerin sorumluluklarının daha az olması ve bağımsız hareket etme eğilimlerinin daha fazla olması onların sinik davranışlarını artırmaktadır.

Tablo 7. Otel İşgörenlerinin Yaşa Göre Örgütsel Sinizm ve İş Performansı Düzeyleri

\begin{tabular}{|c|c|c|c|c|c|c|c|}
\hline BOYUTLAR & YAŞ & $\mathbf{N}$ & $\bar{x}$ & Ss & $\mathbf{F}$ & p & Fark \\
\hline \multirow{3}{*}{ ÖRGÜTSEL SİNIZZM } & 25 YAŞ ALTI & 31 & 2,3065 & ,93773 & \multirow{3}{*}{2,888} & \multirow{3}{*}{0,059} & \\
\hline & 25-35 YAŞ ARASI & 58 & 2,4095 & 1,07891 & & & \\
\hline & 36-45 YAŞ ARASI & 37 & 1,9144 & 90042 & & & \\
\hline \multirow{3}{*}{ BİLIŞSEL BOYUT } & 25 YAŞ ALTI & 31 & 2,2097 & 1,06477 & \multirow{3}{*}{1,522} & \multirow{3}{*}{0,222} & \\
\hline & 25-35 YAŞ ARASI & 58 & 2,4526 & 1,27170 & & & \\
\hline & 36-45 YAŞ ARASI & 37 & 2,0473 & ,92203 & & & \\
\hline \multirow{3}{*}{ DUYGUSAL BOYUT } & 25 YAŞ ALTI & 31 & 2,0806 & 1,14816 & \multirow{3}{*}{1,918} & \multirow{3}{*}{0,151} & \\
\hline & 25-35 YAŞ ARASI & 58 & 2,1552 & 1,19743 & & & \\
\hline & 36-45 YAŞ ARASI & 37 & 1,6959 & 1,04936 & & & \\
\hline \multirow{3}{*}{$\begin{array}{l}\text { DAVRANIŞSAL } \\
\text { BOYUT }\end{array}$} & 25 YAŞ ALTI & 31 & 2,6290 & 1,03455 & \multirow{3}{*}{3,994} & \multirow{3}{*}{0,021} & \multirow{3}{*}{$1>3$} \\
\hline & 25-35 YAŞ ARASI & 58 & 2,6207 & 1,18029 & & & \\
\hline & 36-45 YAŞ ARASI & 37 & 2,0000 & 1,11803 & & & \\
\hline \multirow{3}{*}{ İŞ PERFORMANSI } & 25 YAŞ ALTI & 31 & 3,9217 & 82052 & \multirow{3}{*}{2,611} & \multirow{3}{*}{0,078} & \\
\hline & 25-35 YAŞ ARASI & 58 & 3,7808 & ,94276 & & & \\
\hline & 36-45 YAŞ ARASI & 37 & 4,2085 & 86347 & & & \\
\hline
\end{tabular}

Araştırmaya katılan 31 (\% 24,6) kişi 25 yaş altında, 58 (\%46) kişi 25 ile 35 yaş arasında, 37 (\%29,4) kişi 36 ile 45 yaş arasında bulunmaktadır. Yapılan Anova testi sonucunda ölçülen $p$ değerinin 0.05 'den küçük olması nedeniyle sadece davranışsal boyut için anlamlı bir farklılığın bulunduğu belirlenmiştir. Anlamlı farklılığın Tukey testine göre 25 yaş altı ile 36-45 yaş aralığı için geçerli olduğu belirlenmiştir. 
S. Naktiyok - E. Topçuoğlu - E. Kaygin 12/2 (2020) 1239-1255

Tablo 8. Otel İşgörenlerinin Gelire Göre Örgütsel Sinizm ve İş Performansı Düzeyleri

\begin{tabular}{|c|c|c|c|c|c|c|c|}
\hline BOYUTLAR & GELİR & $\mathbf{N}$ & $\overline{\mathbf{x}}$ & Ss & $\mathbf{F}$ & $\mathbf{p}$ & Fark \\
\hline \multirow{4}{*}{ ÖRGÜTSEL SINİZM } & 2000-3000 TL ARASI & 41 & 2,3801 & 1,03800 & \multirow{4}{*}{ 654 } & \multirow{4}{*}{,582 } & \\
\hline & 3001-4000 TL ARASI & 37 & 2,1036 & 1,06164 & & & \\
\hline & 4001-5000 TL ARASI & 20 & 2,1000 & ,84102 & & & \\
\hline & 5000 TL ÜZERİ & 28 & 2,3095 & 1,02762 & & & \\
\hline \multirow{4}{*}{ BİLIŞSEL BOYUT } & 2000-3000 TL ARASI & 41 & 2,3720 & 1,16340 & \multirow{4}{*}{,426 } & \multirow{4}{*}{ 735 } & \\
\hline & 3001-4000 TL ARASI & 37 & 2,1014 & 1,10312 & & & \\
\hline & 4001-5000 TL ARASI & 20 & 2,3625 & 1,20163 & & & \\
\hline & 5000 TL ÜZERİ & 28 & 2,2946 & 1,11607 & & & \\
\hline \multirow{4}{*}{ DUYGUSAL BOYUT } & 2000-3000 TL ARASI & 41 & 2,1220 & 1,29557 & \multirow{4}{*}{869} & \multirow{4}{*}{,459 } & \\
\hline & 3001-4000 TL ARASI & 37 & 1,9527 & 1,24977 & & & \\
\hline & 4001-5000 TL ARASI & 20 & 1,6625 & 74018 & & & \\
\hline & 5000 TL ÜZERİ & 28 & 2,1339 & 1,03074 & & & \\
\hline \multirow{4}{*}{ DAVRANIŞSAL BOYUT } & 2000-3000 TL ARASI & 41 & 2,6463 & 1,16186 & \multirow{4}{*}{,906 } & \multirow{4}{*}{440} & \\
\hline & 3001-4000 TL ARASI & 37 & 2,2568 & 1,09209 & & & \\
\hline & 4001-5000 TL ARASI & 20 & 2,2750 & 1,24578 & & & \\
\hline & 5000 TL ÜZERİ & 28 & 2,5000 & 1,16468 & & & \\
\hline \multirow{4}{*}{ İŞ PERFORMANSI } & 2000-3000 TL ARASI & 41 & 3,6725 & 84470 & \multirow{4}{*}{1,909} & \multirow{4}{*}{ 132 } & \\
\hline & 3001-4000 TL ARASI & 37 & 4,1081 & 79568 & & & \\
\hline & 4001-5000 TL ARASI & 20 & 4,0929 & ,95918 & & & \\
\hline & 5000 TL ÜZERİ & 28 & 4,0051 & 1,02684 & & & \\
\hline
\end{tabular}

Araştırmaya katılan 41 (\%32,5) kişi 2000 ile 3000 Türk Lirası arasında, 37 (\%29,4) kişi 3001 ile 4000 Türk Lirası arasında, 20 (\%15,9) kişi 4001 ile 5000 Türk Lirası arasında ve 28 (\%22,2) kişi 5001 Türk Lirası üzerinde ücret veya gelir elde etmektedir. Ölçülen $p$ değerinin 0.05 'den büyük olması nedeniyle anlamlı bir ilişki tespit edilememiştir.

Tablo 9. Otel İşgörenlerinin Eğitim Durumuna Göre Örgütsel Sinizm ve İş Performansı Düzeyleri

\begin{tabular}{|c|c|c|c|c|c|c|c|}
\hline BOYUTLAR & MEZUNIYYET & $\mathbf{N}$ & $\bar{x}$ & Ss & $\mathbf{F}$ & p & Fark \\
\hline \multirow{4}{*}{ ÖRGÜTSEL SİNIZM } & LİSANS & 36 & 2,0972 & 1,03596 & \multirow{4}{*}{3,215} & \multirow{4}{*}{0,025} & \multirow{4}{*}{$2>3$} \\
\hline & ÖNLİSANS & 33 & 2,6919 & ,91962 & & & \\
\hline & LISE & 31 & 2,0188 & ,94298 & & & \\
\hline & İLKÖĞRETIM & 26 & 2,1218 & 1,03902 & & & \\
\hline \multirow{4}{*}{ BİLİŞSEL BOYUT } & LISANS & 36 & 2,1597 & 1,16520 & \multirow{4}{*}{3,892} & \multirow{4}{*}{0,011} & \multirow{4}{*}{$\begin{array}{l}2>3 \\
2>4\end{array}$} \\
\hline & ÖNLİSANS & 33 & 2,8258 & 1,13448 & & & \\
\hline & LISE & 31 & 2,0081 & 1,09446 & & & \\
\hline & İLKÖĞRETIMM & 26 & 2,0481 & ,93813 & & & \\
\hline \multirow{4}{*}{ DUYGUSAL BOYUT } & LISANS & 36 & 1,8958 & 98629 & \multirow{4}{*}{1,650} & \multirow{4}{*}{0,181} & \\
\hline & ÖNLİSANS & 33 & 2,3485 & 1,21825 & & & \\
\hline & LİSE & 31 & 1,7419 & 1,09636 & & & \\
\hline & İLKÖĞRETİM & 26 & 2,0192 & 1,29407 & & & \\
\hline \multirow{4}{*}{ DAVRANIŞSAL BOYUT } & LİSANS & 36 & 2,2361 & 1,17404 & \multirow{4}{*}{2,486} & \multirow{4}{*}{0,064} & \\
\hline & ÖNLİSANS & 33 & 2,9015 & 1,03821 & & & \\
\hline & LISE & 31 & 2,3065 & 1,12862 & & & \\
\hline & İLKÖĞRETİM & 26 & 2,2981 & 1,20212 & & & \\
\hline İŞ PERFORMANSI & LİSANS & 36 & 3,9325 & 1,06055 & 0,045 & 0,987 & \\
\hline
\end{tabular}




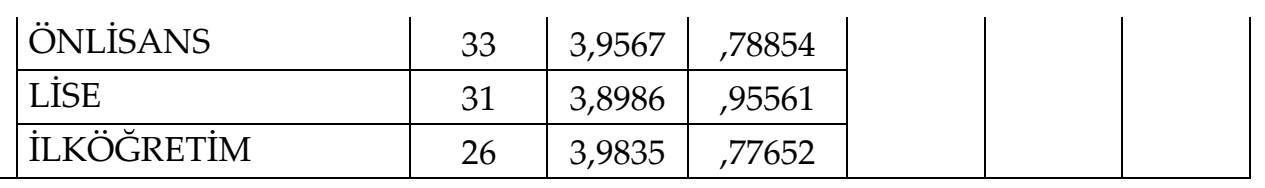

Araştırmaya katılan 36 (\%28,6) kişi lisans mezunu, 33 (\%26,2) kişi önlisans mezunu, 31 (\% 24,6) kişi lise mezunu, $26(\% 20,6)$ kişi ilköğretim mezunu olduğu tespit edilmiştir. Mezuniyet durumu ile örgütsel sinizm, bilişsel boyutları arasında ölçülen $\mathrm{p}$ değerinin 0.05 'den küçük olması nedeniyle anlamlı bir ilişki bulunmaktadır. Tespit edilen farklılıkların Tukey testine göre önlisans mezunu olanlar ile lise ve ilköğretim mezunları arasında olduğu belirlenmiştir. Duruma sinizm açısından bakıldığında önlisans mezunlarının diğer gruplara göre sinizm algılarının daha yüksek olduğu görülmektedir. Eğitim seviyesi düşük olan grubun sinizm seviyesinin düşük olması, onların başka bir işletmede iş bulabilme olasılığının düşük olmasına ve eğitimleri gereği eleştiri durumlarının yetersiz kalmasına bağlanabilir. Lisans mezunlarının sinik algılarının önlisansa göre düşük olması da lisans mezunlarının eğitimleri doğrultusunda örgüt ile daha fazla bütünleşmeleri ve örgütü sahiplenerek daha iyi yerlere getirme algısı ile hareket etmelerinden kaynaklandığı ifade edilebilir. İş performansı olarak durum değerlendirildiğinde eğitim seviyesinin yükselmesi ile performansın arttığ1 görülmüştür ki bu beklenen bir durumdur.

\section{Sonuç}

Yapılan çalışma Kars İl Merkezinde bulunan otellerdeki 126 işgöreni kapsamaktadır. Bu kişilerden 51'i erkek, 75 'si ise kadındır, otel işgörenlerinin gelirlerin asgari ücretin üstünde ve eğitim durumunun yüksek olduğu, deneyim sürelerinin kısalığı ve 45 yaş sonrası işgörenin bulunmadığı göze çarpmaktadır.

Yapılan çalışma sonucunda örgütsel sinizm, bilişsel boyut, duygusal boyut arasında anlamlı bir ilişkinin bulunmadığı sadece davranışsal boyut ile iş performansı arasında düşük düzeyde negatif yönlü ve anlamlı bir ilişkinin bulunduğu tespit edilmiştir. Akdemir vd. (2016), Genç (2018), Kâhya (2013), Şantaş vd. (2016), Topcu vd. (2017), Uzun (2018), Yılmaz ve Polatcı (2018) tarafından örgütsel sinizmin ile iş performansı arasında negatif yönlü ve anlamlı bir ilişki belirlenmiş ise de yapılan çalışma sonucunda aynı tespitlere ulaşılamamıştır. Bu farklılığın otellerde işgören sayısının 15 ile 30 arasında değişmesi sonucunda daha samimi ilişkilerin ortaya çıkması ve ortak paylaşımların yüksek olması nedeniyle işgörenlerin sinizm iş performansını ilişkilendirmediğinden kaynaklandığı ifade edilebilir.

Evli bireylerin günlük yaşam içerisinde aldıkları sorumlulukların bekarlara göre fazla olması nedeniyle, daha az sinik davrandıkları belirlenmiştir. Bunun nedeninin çocukların bakımı, yemek yapma ve ev işleri gibi birçok hususta eşler arasında koordineli ve ortak hareket etmenin bir sonucu olarak geliştiği düşünülmektedir. Benzer şekilde Gün (2017:11) tarafından bekâr otel işgörenlerinin evli otel işgörenlerine göre daha sinik olduğu belirlenmiştir. Bekâr işgörenlerin sorumluluklarının daha az olması ve bağımsız hareket etme eğilimlerinin daha fazla olması onların sinik davranışlarını artırmaktadır.

Yaş ile örgütsel sinizm arasında bulunan farklılığın 25 yaş altı ile 36-45 yaş aralığı için geçerliliği olduğu belirlenmiştir. Gün (2017:11) tarafından yapılan araştırmada yaşa göre otel işgörenleri arasında anlamlı bir farklılık tespit edilememiştir. Özgener vd. (2008) tarafından yapılan araştırmaya göre yaşları küçük olan işgörenlerin, yaşlı işgörenlere göre daha sinik olduğu tespit edilmiştir. Genç işgörenlerin hırslı olması ve hızlı bir şekilde mevki sahibi olmak istemelerinin bir sonucu olarak daha sinik oldukları değerlendirilmektedir. Yapılan çalışma sonucunda işgörenlerin örgüt içerisinde çalıştıkça ve yaş aldıkça hayata ve dolayısı ile örgüte karşı muhalif davranışları daha da azalacak ve sinik algıları daha da düşecektir. Ancak genç işgörenlerin yaşam tecrübelerinin az olması, başka işletmelerde iş bulma gibi kaygılarının az olması gibi durumlar onların daha sinik davranışlar sergilemesine neden olmaktadır.

Afacan Fındıklı (2016:54) ile Alper Ay ve Keleş (2017:199) tarafından eğitimin işgörenlerin, iş performansını etkileyen önemli bir değişken olduğu belirlenmiştir. Örgütsel sinizm ile eğitim arasında özellikle önlisans ile diğer eğitim düzeyleri arasında anlamlı bir farklılı̆̆ın bulunduğu görülmüştür. Ülkemizde daha nitelikli ve kalifiye iş gücünün yetiştirilmesini amaç edinerek hemen hemen her ilçeye açılan meslek yüksek okullarının istenmeyen bir sonucu olarak eğitim kalitesi düşmüş ve bu okullardan mezun olanların sayısı artmıştır. Ayrıca küçük ilçelerde turizm alanında nitelikli otel ve lokanta bulunmaması sebebiyle bu küçük ilçelere kurulan turizm meslek yüksekokullarının uygulama imkânları kısıtlı kalarak kişilerin deneyim ile öğrenimi birleştirmeleri mümkün olmamıştır (Kılıç ve Yılmaz, 2018:14). Sınavsız geçiş sistemi ve oluşan engellerin bir 


\section{S. Naktiyok - E. Topçuoğlu - E. Kaygin 12/2 (2020) 1239-1255}

sonucu olarak önlisans ile lise arasında toplum nezdinde farklılık azalmış olup bununda önlisans mezunu işgörenleri daha sinik bir hale getirdiği düşünülmektedir. Bu sinik özelliklere rağmen önlisans mezunu işgörenlerin konuyla ilgili eğitim almasının bir sonucu olarak diğer işgörenlere göre iş performanslarının daha yüksek olduğu belirlenmiştir.

İşgörenlerin sinik davranışları sonucunda kendilerinin, iş arkadaşlarının, müşterilerin ve işletmelerin zarar görmesi mümkündür. Ortaya çıkan zararlar sonucunda işgörenlere ceza hukuku kapsamında parasal ve özgürlüğü kısıtlayan cezaların uygulanabilmektedir. Ayrıca tazminat ödeme, iş akdinin sonlandırılması, kıdem ve tazminat haklarının kaybedilmesi gibi birçok yasal yaptırımda bu kapsamda değerlendirilebilmektedir (Koç, 2020:50). Yaşanan olumsuz olaylar sonucunda işletmeler için büyük itibar ve maddi kayıplar söz konusu olabilmektedir.

Kars'ta konaklama tesisleri ağırlıklı olarak 10 ile 20 oda arasında kapasiteye sahip düşük yıldızlı otellerden oluşmaktadır. Mevcut durumda bu otellerin günlük konaklama imkânı dışında çok fazla imkân sunduğunu söyleyebilmek mümkün değildir. Kars İlinde 5 yıldızlı otel sadece bir adet olup söz konusu otel Sarıkamış İlçesinde bulunmaktadır. Bu kapsamda Kars İl Merkezine 5 yıldızlı bir otelin yapılması gerektiği değerlendirilmektedir. Sağlıklı bir turizm potansiyelinin yakalanması amacıyla 5 yıldızlı otel ile beraber 4 yıldızlı otellerinde yapılması gerekmektedir. Hizmet kalitesinin ve denetim seviyesinin arttırılması amacıyla belediye belgeli otellerin, yıldızlı turistik otel statüsüne kavuşturulması da önem arz etmektedir. Diğer önemli bir unsurda Kars'ta yaygınlaşmaya başlayan tarihi metruk binaların butik otel olarak yeniden hayata döndürülmesi ile karlılığın ve gelen misafirlerin memnuniyetinin artırılması uygulamalarının devam ettirilmesi gerektiği hususudur.

Kars'ta yaz aylarında otel kapasiteleri boş kalmakta ve ağırlıklı olarak kış aylarında yoğunluk görülmektedir. Yaşanan boşluk nedeniyle bazı işgörenlerin işine son verilmekte veya ücretsiz izin uygulamaları hayata geçirilmektedir. Yapılan bu uygulamalar personel arasında huzursuzluğa ve iş performansında düşüşe neden olmaktadır. Alp Dağları eteklerinde bulunan kış turizminin yaygın olduğu İsviçre ve Avusturya'da bulunan konaklama işletmelerinde çeşitli futbol kampları ve turnuvaları düzenlenerek boş kapasite ve istihdam sorunu giderilmektedir. Buradan hareketle yaz aylarında otellerin doluluk oranlarının artırılması maksadıyla spor tesislerinin kurulmalı ve kampa girecek spor takımları için teşvik edici uygulamalar geliştirilmelidir.

Yapılan araştırma öncelikle 5 adet 3 ve 4 yıldızlı oteli kapsayacak şekilde dizayn edilmiş, ulaşılan evrenin düşük düzeyde olduğunun görülmesi ile Kars İl Merkezinde bulunan belediye belgeli 100 odalı 2 adet otelde çalışmaya dâhil edilmiştir. Yapılan araştırma otel işgörenlerinin örgütsel sinizm ve iş performansı arasındaki ilişkiyi ölçen ilk çalışma olması sebebiyle önem arz etmekte olup daha geniş kitlelere çalışmanın uygulanması sonucunda yeni bulgu ve bilgilerin elde edileceği düşünülmektedir. Ayrıca bu alanda çalışma yapacak olan kişilerin Toplum 5.0, işkoliklik, örgütsel sessizlik, işe adanmışlık ve örgütsel sinizm alanlarını da kapsayacak şekilde yeni çalışmalar yapması önemli olacaktır.

\section{Kaynaklar}

Abraham, R. (2000). Organizational cynicism: Bases and consequences, Genetic, Social and General Psychology Monographs, 126(3), 269-292.

Afacan Findıklı, M. (2016). Relationship between cyberloafing and work performance: comparison of health and textile industry workers, International Journal of Social Inquiry, 9 (1), 33-62.

Akdemir, B., Kırmızıgül, B. and Zengin, Y. (2016). Örgütsel sinizm ile iş performansı arasındaki ilişki ve bir araştırma, Kahramanmaraş Sütçü İmam Üniversitesi İktisadi ve İdari Bilimler Fakültesi Dergisi, 6 (2), 115130.

Alpar, R. (2013). Uygulamalı Çok Değişkenli İstatistik Yöntemler. (4.Basım), Ankara, Detay Yayıncllık

Alper Ay, F. and Keleş, K. (2017). Etkileşimci ve dönüşümcü liderlik tarzlarının işten ayrılma niyeti ve iş performansı üzerinde etkisi, Gümüşhane Üniversitesi Sağlık Bilimleri Dergisi, 6 (4), 193-203.

Altınöz, M., Çöp, S. and Sığındı, T. (2011). Algılanan örgütsel bağlılık ve örgütsel sinizm ilişkisi: Ankara'daki dört ve beş yıldızlı konaklama işletmeleri üzerine bir araştırma, Sosyal Ekonomik Araştırmalar Dergisi, $11(21), 285-316$. 
S. Naktiyok - E. Topçuoğlu - E. Kaygın 12/2 (2020) 1239-1255

Andersson, L.M. (1996). Employee cynicism: An examinationusing a contract violation framework, Human Relations, 49 (11), 1395-1418.

Avunduk, Y. (2016). Duygusal zekânın iş performansı üzerindeki etkisi: Tıp doktorları ile toplu ulaşım şoförleri üzerinde karşılaştırmalı alan uygulaması, Yayınlanmamış Doktora Tezi, İstanbul, İstanbul Ticaret Üniversitesi.

Balay, R., Kaya, A. and Cülha, A. (2013). Örgüt kültürü ve örgütsel sinizm ilişkisi, Cumhuriyet Üniversitesi İktisadi ve İdari Bilimler Dergisi , 14 (2) , 123-144.

Başaran, E. (1991). Örgütsel davranış, Ankara: Gül Yayınevi.

Bayram, L. (2006). Geleneksel performans değerlendirme yöntemlerine yeni bir alternatif: 360 derece performans değerlendirme, Sayıştay Dergisi, 62, 47-65.

Bernerth, J.B., Armenakis, A.A., Feild, H.S. and Walker H.J. (2007). Justice, cynicism, and commitment: A study of important organizational change variables, The Journal of Applied Behavioral Science, 43 (3), 303-326.

Brandes, P., Dharwadkar, R. and Dean, J.W. (1999). Does organizational cynicism matter? Employee and supervisor perspectives on work outcomes, The 36th Annual Meeting of the Eastern Academy of Management Proceedings, Philadelphia, 150-153.

Brandes, P. and Das, D. (2006). Locating behavioral cynicism at work: Construct issues and performance implications, Employee Health, Coping and Methodologies, 5, 233-266.

Büte, M. (2011). Etik iklim, örgütsel güven ve bireysel performans arasındaki ilişki, Atatürk Üniversitesi İktisadi ve İdari Bilimler Dergisi, 25 (1), 171-192.

Büyüköztürk, Ş., Çakmak, E.K., Akgün, Ö.E., Karadeniz, Ş. and Demirel, F. (2012). Bilimsel Araştırma Yöntemleri, Ankara: Pegem Akademi Yayıncilık.

Chiu, S.K. (2004). The linkage of job performance to goal setting, work motivation, team building, and organizational commitment in the high-tech industry in Taiwan, Yayınlanmamış Doktora Tezi, Florida, Nova Southeastern University.

Choo, F. (1986). Job stress, job performance, and auditor personality characteristics, A Journal of Practice and Theory, 5(2), 1-34.

Çakır, A. and Gözoğlu, Ö. (2019). Algılanan kurumsal itibarın iş performansı ve işten ayrılma niyetine etkisi: Şanlıurfa İli konaklama işletmeleri üzerine bir araştırma, Econharran, 3 (4), 46-71.

Çalışkan, S., Ünal, Z., Kalafatoğlu, Y., Akün, F. and Üçler, Ç. (2015). The relationship among leaders' perceived cultural intelligence, employees' diversity climate perception, employees' openness to experience and organizational cynicism: A research in tourism sector. İş ve İnsan Dergisi, 2 (1), 1-11.

Çetinkaya, F. and Özkara, B. (2015). Hizmet işletmelerinde psikolojik sözleşme ihlalleri ve örgütsel sinizm ilişkisi: Kapadokya Bölgesi 4 ve 5 yıldızlı otel işletmelerinde bir araştırma, Kastamonu Üniversitesi İktisadi ve İdari Bilimler Fakültesi Dergisi, 9 (3), 72-91.

Çetinsöz, B.C. and Akdağ, G. (2015). Otel çalışanlarının sahip oldukları kişilik özellikleri ve iş performansı ilişkileri: Antalya' da faaliyet gösteren beş yıldızlı otellerde bir uygulama, Turizm Akademik Dergisi, 2 (1), 1-13.

Çöl, G. (2008). Algılanan güçlendirmenin işgören performansı üzerine etkileri, Doğuş Üniversitesi Dergisi, 9 (1), 35-46.

Dean, J.W., Brandes, P. and Dharwadkar, R. (1998). Organizational cynicism, Academy of Management Review, 23(2), 341-352.

Demir, M. (2015). Konaklama işletmelerinde birey-örgüt uyumunun iş performansı ve işte kalma niyeti üzerine etkisi, Journal of Tourism Theory and Research, 1(2), 57-71.

Demir, M., Ayas, S. and Yıldız, B. (2018). Örgütsel sinizm ve işe yabancılaşma ilişkisi: Beş yıldızlı otel çalışanları üzerine bir araştırma, Yönetim Bilimleri Dergisi, 16(32), 231-254. 
S. Naktiyok - E. Topçuoğlu - E. Kaygın 12/2 (2020) 1239-1255

Demir, Ş.Ş. and Öztürk, İ. (2019). Atmosferin yiyecek içecek departmanında çalışanların iş performansı üzerine etkisi. International Journal of Social Sciences and Education Research, 5(4), 361-383.

Denis, D.J. (2019). SPSS Data Analysis for Univariate, Bivariate, and Multivariate Statistics, New Jersey, John Wiley\&Sons, Inc.

Doğan, H. (2018). Örgütsel adalet algısı ile iş performansı arasındaki ilişki, Kastamonu Üniversitesi İktisadi ve İdari Bilimler Fakültesi Dergisi, 20 (2), 26-46.

Efeoğlu, Y. and İplik, A. (2011). Algilanan örgütsel adaletin örgütsel sinizm üzerindeki etkilerini belirlemeye yönelik ilaç sektöründe bir uygulama, Çukurova Üniversitesi Sosyal Bilimler Enstitüsü Dergisi , 20 (3), 343-360.

Ekinci, N. (2019). Sinizm: Türkiye'de sağlık alanında 2011-2018 yılları arasındaki çalışmalar üzerine bir değerlendirme, İzmir Kâtip Çelebi Üniversitesi İktisadi ve İdari Bilimler Fakültesi Dergisi, 2 (2), 161-175.

Erdoğan, İ. (1991). İşletmelerde personel seçimi ve başarı değerleme teknikleri, İstanbul, İ.Ü. İşletme İktisadı Enstitüsü Yayınları.

Fitzgerald, M.R. (2002). Organizational cynicism: Its relationship to perceived organizational in justice and explanatory style, Yayımlanmamış doktora tezi. Ohio, University of Cincinnati.

Genç, E. (2018). Kamu çalışanlarında algılanan örgütsel desteğin iş performansına etkisinde örgütsel sinizmin aracılık rolü, Cumhuriyet Üniversitesi İktisadi ve İdari Bilimler Dergisi, 19 (2), 169-183.

Gün, G. (2016). Örgüt kültürü tiplerinin örgütsel sinizm algısına etkisi: Bitlis İli otel işletmelerinde bir alan araştırması, Bitlis Eren Üniversitesi İktisadi Ve İdari Bilimler Fakültesi Akademik İzdüşüm Dergisi, 1 (1) , 2855.

Gün, G. (2017). Otel işletmeleri çalışanlarının örgütsel sinizm algılarının bazı demografik değişkenlere göre incelenmesi, Bitlis Eren Üniversitesi İktisadi ve İdari Bilimler Fakültesi Akademik İzdüşüm Dergisi, 2 (1), 122.

Güzel, B. and Ayazlar, G. (2014). Örgütsel adaletin örgütsel sinizm ve işten ayrılma niyetine etkisi: Otel işletmeleri araştırması, Karamanoğlu Mehmetbey Üniversitesi Sosyal ve Ekonomik Araştırmalar Dergisi, 16 (26), 133-142.

Hair, J., Anderson, E.R., Tahtam, L.R. and Black, C.W. (2014). Multivariate data analysis. (7. Basım), Essex, Pearson Education Limited.

Helvacı, M.A. and Çetin, A. (2012). İlköğretim okullarında görev yapan öğretmenlerin örgütsel sinizm düzeylerinin belirlenmesi (Uşak İli Örneği), Turkish Studies, 7 (3), 1475-1497.

İbrahimağaoğlu, Ö. and Can, E. (2017). Örgütsel sinizm ile örgütsel tükenmişlik arasındaki ilişkinin incelenmesi: Hizmet sektörü çalışanları üzerine ampirik bir araştırma. Yıldız Sosyal Bilimler Enstitüsü Dergisi, 1 (2), 181-205.

James, M.S.L. (2005). Antecedents and consequences of cynicism in organizations: An examination of the potential positive and negative effects on school systems. A Dissertation Presented to The College of Business, Florida, The Florida State University.

Kâhya, C. (2013). Örgütsel sinizm, iş performansını etkiler mi? İş tatminin aracılık etkisi, Global Journal of Economics and Business Studies, 2 (3), 34-46.

Karacaoğlu, K. and İnce, F. (2012). Brandes, Dharwadkar ve Dean'in (1999) Örgütsel Sinizm Ölçeği Türkçe Formunun geçerlilik ve güvenilirlik çalışması: Kayseri Organize Sanayi Bölgesi Örneği, Business and Economics Research Journal, 3 (3), 77-92.

Karadal, H. and Arasli, H. (2009). The Impact of superior politics on frontline employees' behavioral and psychological out comes. Social Behavior and Personality: An International Journal, 37 (2), 175-190. 
S. Naktiyok - E. Topçuoğlu - E. Kaygın 12/2 (2020) 1239-1255

Kaşka Üreten, Z. and Gemlik, H. (2016). Sağlık meslek gruplarının örgütsel sinizm düzeylerini ölçmeye yönelik bir araştırma: kamu hastanesi ile özel hastane karşılaştırması, Hacettepe Sağglı İdaresi Dergisi, 19 (4), 481-502.

Kaygin, E. and Kavak, O. (2017). Determination of the level of organizational sinizm on academic staff. Press Academia Procedia (PAP), 3, 808-814.

Kılıç, Y. and Yılmaz, E. (2018). Mesleki eğitimin önemine ilişkin bir durum çalışması, Academia Eğitim Araştırmaları Dergisi, 3 (1), 1-16.

Kirkman, B.L. and Rosen, B. (1999). Beyond self-management: Antecedents and consequences of team empowerment. Academy of Management Journal, 42, 58-74.

Koç, C. (2020). Suçun konusunun yokluğu durumunda teşebbüse elverişlilik sorunu, Türkiye Barolar Birliği Dergisi, 147, 49-73.

Korkmaz Orhan, B. and Ünüvar, Ş. (2019). Otel çalışanlarının örgütsel adalet algılarının örgütsel sinizm düzeyleri üzerindeki etkisinin incelenmesi, Safran Kültür ve Turizm Araştırmaları Dergisi, 2(3), 443-462.

Kosa, G. (2019). Örgütsel sinizm ve iş doyumu ilişkisi: Banka çalışanları üzerine bir araştırma, Kafkas Üniversitesi İktisadi ve İdari Bilimler Fakültesi Dergisi, 10 (19), 182-213.

Köksal, B. A. (1994). İstatistik Analiz Metodları. İstanbul, Çağlayan Kitabevi.

Liceli, M. and Hassan, A. (2019). Otel yöneticilerinin kullandıkları güç kaynaklarının işgörenlerin örgütsel sinizm algıları üzerine etkisi, Gastroia: Journal of Gastronomy And Travel Research, 3 (3), 411-436.

Motowidlo, S.J. and Scotter, V. (1994). Evidence that task performance should be distinguished from contextual performance, Journal of Applied Psychology, 79 (4), 475-480.

Mowday, R.T.,Steers, R.M. and Porter, L.W. (1979). The measurement of organizational commitment, Journal of Vocational Behavior, 14, 224-247.

Özgener, Ş., Ögüt, A. and Kaplan, M. (2008). Örgütsel Adaletsizlik Kavramı, Boyutları ve Yönetimi, Özdevecioğlu, M. and Karadal, H.,Örgütsel Davranışta Seçme Konular Organizasyonların Karanlı Yönleri ve Verimlilik Azaltıcı Davranışlar, İlke Yayınevi, Ankara, 53-72.

Özgül Katlav, E. and Şahin Perçin, N. (2019). Algılanan etkileme taktiklerinin iş performansı üzerindeki etkisini belirlemede kontrol odağının düzenleyici rolü: Otel işletmelerinde bir uygulama, Sosyal Bilimler Araştırmaları Dergisi, (2019-Özel Sayı) , 225-244.

Polat, Ş. (2019). Öğretim doyumu ve iş performansı ilişkisinin öğretmen görüşlerine göre incelenmesi. Bolu Abant İzzet Baysal Üniversitesi Eğitim Fakültesi Dergisi, 19(2), 641-651.

Sarı, Y. and Doğantekin, A. (2016). Konaklama işletmelerinde örgütsel etik iklim ve örgütsel sinizm ilişkisi üzerine bir araştırma, İşletme Araştırmaları Dergisi, 8 (3), 222-250.

Sigler, T.H. and Pearson, C.M. (2000). Creating an empowering culture: examining the relationship between organizational culture and perceptions of empowerment, Journal of Quality Management, 5, 27-52.

Şahin, S. and Çankır, B. (2019). Sürdürülebilir kalite algısı ve iş performansı: Çalışmaya tutkunluğun aracı rolü, Çukurova Üniversitesi Sosyal Bilimler Enstitüsü Dergisi, 28 (3), 196-211.

Şantaş, F., Uğurluoğlu, Ö., Kandemir, A. and Çelik, Y. (2016). Sağlık çalışanlarında örgütsel sinizm, iş performansı ve örgütsel özdeşleşme düzeyleri arasındaki ilişkilerin incelenmesi, Gazi Üniversitesi İktisadi ve İdari Bilimler Fakültesi Dergisi, 18 (3), 867-886.

T.C. Kültür Bakanlığı (2020). https://kars.ktb.gov.tr/Eklenti/56103,kars-merkez-ve-ilcelerde-bulunan-turizmisletme-belgeli-.docx?0 (Erişim tarihi: 05 Ocak 2020).

Topcu, M., Beğenirbaş, M. and Turgut, E. (2017). Örgütsel sinizm, zorunlu örgütsel vatandaşlık davranışları ve iş tatmininin bireysel iş performansına etkilerinin belirlenmesine yönelik imalat sanayide bir uygulama, Yönetimve Ekonomi: Celal Bayar Üniversitesi İktisadi ve İdari Bilimler Fakültesi Dergisi, 24 (2), 505-522. 
S. Naktiyok - E. Topçuoğlu - E. Kaygın 12/2 (2020) 1239-1255

Uzun, T. (2018). Öğretmenlerin örgütsel sinizm tutumlarının iş performanslarına etkisi: Örgütsel vatandaşlık davranışının aracı rolü, Abant İzzet Baysal Üniversitesi Eğitim Fakültesi Dergisi, 18 (3), 1800-1821.

Wilkerson, J.M., Evans, W.R. and Davis, W.D. (2008). A test of coworkers' influence on organizational cynicism, bad mouthing and organizational citizenship behavior, Journal of Applied Social Psychology, 38(9), 2273-2292.

Yaşlığlu, M . (2017). Sosyal bilimlerde faktör analizi ve geçerlilik: keşfedici ve doğrulayıcı faktör analizlerinin kullanılması, İstanbul Üniversitesi İşletme Fakültesi Dergisi, 46, 74-85.

Yılmaz, H. and Polatcı, S. (2018). Örgütsel adalet algısı ve personel güçlendirmenin iş performansına etkisi: Örgütsel sinizmin rolü, International Journal of Social Science, 1 (2), 286-308. 